\title{
Physiology of Olive Leaf Abscission Induced by Phosphorus
}

\author{
Hisashi Yamada ${ }^{1}$ and George C. Martin \\ Department of Pomology, University of California, Davis, CA 95616
}

Additional index words. Olea europaea, $\mathrm{Al}_{2} \mathrm{O}_{3}, \mathrm{AOA}, \mathrm{CoCl}_{2}, \mathrm{AVG}, \mathrm{N}_{2}$, ethylene

\begin{abstract}
Adding $\mathrm{Al}_{2} \mathrm{O}_{3}$ to 8-hydroxyquinoline citrate (8-HQC) solution did not alter the sensitivity of the leaf abscission zone to external ethylene. Exogenous ethylene at $791 \mathrm{nl} \cdot \mathrm{llter}^{-1}$ for 72 to 120 hours and at $193 \mathrm{nl}^{-l i t e r}{ }^{-1}$ for 120 hours induced

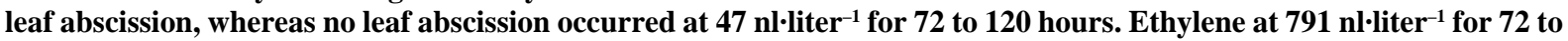
120 hours increased ethylene evolution, but the amount of ethylene evolved from the explants does not seem to be enough to induce leaf abscission. Three different ethylene inhibitors-aminooxyacetic acid ( $\mathrm{AOA}), \mathrm{CoCl}_{2}$, and aminoethoxyvinylglycine (AVG) - were used to determine whether P-induced leaf abscission was mediated through elevated ethylene evolution. Although $\mathrm{AOA}$ and $\mathrm{CoCl}_{2}$ failed to inhibit ethylene evolution from the explants stem-fed with $\mathrm{NaH}_{2} \mathrm{PO}_{4}$, AVG inhibited ethylene evolution. Each inhibitor, except $5 \mathrm{mM} \mathrm{CoCl}_{2}$, promoted leaf abscission when administered alone or with $P$. Our results reveal that $P$-induced olive leaf abscission may occur without elevated ethylene evolution. At 40 or $75 \mathrm{~mm} \mathrm{NaH}_{2} \mathrm{PO}_{4}$, abscission did not occur until explants were removed from $\mathrm{N}_{2}$ and placed in ambient air.
\end{abstract}

Studies of fruit loosening agents that facilitate mechanical olive harvest have been conducted for many years. Foliar sprays with ethylene-releasing compounds, such as 2-(chloroethyl)-phosphonic acid (ethephon), have induced fruit abscission (Ben-Tal and Lavee, 1976; Hartmann et al., 1970; Lang and Martin, 1987; Martin et al., 1981). However, these treatments have also caused excessive leaf abscission, which results in reduced yield and entry of olive knot bacteria the following season (Martin, 1986). No chemicals tested to date have performed satisfactorily due to lack of fruit abscission action or excessive leaf loss.

Recently, Banno et al. (1993) found that $\mathrm{NaH}_{2} \mathrm{PO}_{4}$ induced leaf and fruit abscission of olive explants in stem-feeding treatments. They also observed fruit abscission with minimal leaf loss after foliar spray treatment and suggested a potential strategy to loosen fruit for mechanical harvest using $\mathrm{NaH}_{2} \mathrm{PO}_{4}$ sprays.

Elevated ethylene levels resulted in olive leaf and fruit abscission (Lang and Martin, 1987, 1989; Weis et al., 1988), and the extent of leaf abscission was correlated with the early rate of ethylene evolution from individual leaves (Lavee and Martin, 1981a-c). Lavee and Martin (1981a) also indicated that a robust ethylene or ethephon treatment was required at least $50 \mathrm{~h}$ before olive leaf abscission was induced. In contrast, ethylene evolution from olive explants stem-fed with $\mathrm{NaH}_{2} \mathrm{PO}_{4}$ evolved ethylene coincidentally with leaf abscission (Banno et al., 1993; BurnikTiefengraber et al., 1994). Banno et al. (1993) also found that $\mathrm{Al}_{2} \mathrm{O}_{3}$ delayed phosphate- and ethephon-induced abscission. $\mathrm{Al}_{2} \mathrm{O}_{3}$ binds phosphate; however, it might also decrease abscission-zone sensitivity to phosphate treatment. Burnik-Tiefengraber et al. (1994) used aminooxyacetic acid (AOA), an ethylene inhibitor, to determine whether $\mathrm{P}$ elevated ethylene levels, which then enhanced abscission. They observed that AOA did not measurably affect leaf abscission or ethylene evolution induced by $\mathrm{NaH}_{2} \mathrm{PO}_{4}$. Other investigators (Fuchs et al., 1981; Sobolewska and Plich, 1986) suggested that phosphate inhibited ethylene biosynthesis in some higher plants and that the site of its control was the conversion of 1-amino-cyclopropane-1-carboxylic acid (ACC) to ethylene.

Received for publication 3 Dec. 1993. Accepted for publication 24 Feb. 1994. The cost of publishing this paper was defrayed in part by the payment of page charges. Under postal regulations, this paper therefore must be hereby marked advertisement solely to indicate this fact.

${ }^{1}$ On sabbatical, Faculty of Agriculture, Niigata Univ., Niigata 950-21, Japan.
The mechanism of P-induced abscission is unclear, although some suggestions have been provided by Banno et al. (1993) and Burnik-Tiefengraber et al. (1994). The purpose of our research was to test four hypotheses on the mechanism of P-induced leaf abscission as follows: 1) $\mathrm{Al}_{2} \mathrm{O}_{3}$ decreases abscission-zone sensitivity to ethylene; 2) a low level of external ethylene induces leaf abscission via increased endogenous ethylene evolution; 3) Pinduced abscission is mediated through increased ethylene production; and 4) $\mathrm{O}_{2}$ is required for P-induced leaf abscission.

\section{Materials and Methods}

Plant materials. One-year-old vegetative shoots on "off-year" 'Manzanillo' olive trees were collected as needed from March to July 1993 from the orchard at the Univ. of California, Davis. Excised shoots were placed in buckets of water for transport to the laboratory. Shoots with five pairs of leaves were recut under water to 20 to $25 \mathrm{~cm}$ long, and four shoots were placed in a $50-\mathrm{ml}$ flask of either the control solution containing $200 \mathrm{mg} \cdot \operatorname{liter}^{-1} 8$ hydroxyquinoline citrate (8-HQC) (Burnik-Tiefengraber et al., 1994) or treatment solutions with 8-HQC. Using 8-HQC extends explant vitality by several weeks.

Aluminum oxide effect. Explants continuously stem-fed with 8$\mathrm{HQC}$ or 8-HQC $+100 \mathrm{mg} \cdot \mathrm{liter}^{-1} \mathrm{Al}_{2} \mathrm{O}_{3}$ (saturated) were exposed to three ethylene concentrations $\left(1,2\right.$, and $\left.4 \mu \mathrm{l} \cdot \mathrm{liter}^{-1}\right)$ plus air only (control) in the gas-flow system (Lang and Martin, 1989). High humidity was maintained by laying wet paper towels at the bottom of the jar and passing air alone or air mixed with ethylene through the jar. Eight shoots in two flasks were provided for each treatment and placed in the jar. Explants were removed from the flowthrough system to ambient laboratory conditions at 20C in the same room after the treatment periods described in detail in the footnote of Fig. 1 to observe leaf abscission for the following 7 days. Cumulative leaf abscission was recorded every day as the number of leaves that abscised naturally and those that separated by the gentle touch of a finger.

Low concentration of ethylene treatment. Using the gas-flow system described above, shoots stem-fed with 8-HQC solutions were exposed to ethylene at $0,47,193$, and $791 \mathrm{nl} \cdot \mathrm{liter}^{-1}$ for 72,96 , or $120 \mathrm{~h}$. Explants were removed from the jars and placed in the same controlled-temperature room at $20 \mathrm{C}$ after ethylene treatment. Leaf abscission was measured every $24 \mathrm{~h}$ after removing the 
explants from the flow-through system for 3 to 5 days depending on treatment duration. A flask containing four shoots per treatment was transferred into a 1.88-liter jar with a stopper for $2 \mathrm{~h}$, and then a 10-ml gas sample was taken from each jar for ethylene analysis by gas chromatography (Goren et al., 1988). Ethylene was measured 2, 6, and $24 \mathrm{~h}$ after removing the explants from the external ethylene treatments.

Ethylene biosynthesis inhibitors. Shoots were prepared in the same way as described above, and four shoots per treatment were put in a flask and continuously stem-fed with solutions containing 8-HQC, 8-HQC + $40 \mathrm{~mm} \mathrm{NaH}_{2} \mathrm{PO}_{4}$, or 8-HQC + $75 \mathrm{~mm} \mathrm{NaH}_{2} \mathrm{PO}_{4}$ combined with $\mathrm{AOA}, \mathrm{CoCl}_{2}$, or aminoethoxyvinylglycine (AVG) at $1.25,2.5$, or $5.0 \mathrm{~mm}$. Explants were placed in the laboratory at 20C, and leaf abscission and ethylene evolution from the explants were measured every day for the 10 days of treatment in the same manner as described before. Ethylene production was no longer measured when the percentage of leaf abscission attained $90 \%$ or more, because even the small amount of evolved ethylene from the shoot stems might affect the ethylene evolution calculated on a per- leaf basis. The experiment was repeated five times during June to early July.

Nitrogen gas effect. Explants stem-fed with 8-HQC, 8-HQC + $40 \mathrm{~mm} \mathrm{NaH}_{2} \mathrm{PO}_{4}$, or 8-HQC $+75 \mathrm{~mm} \mathrm{NaH}_{2} \mathrm{PO}_{4}$ were placed in the jars connected with the gas-flow system described above. Since $\mathrm{N}_{2}$ gas severely damaged leaves under high humidity in a preliminary experiment, humidity was not adjusted in this experiment. Shoots were exposed to air or $100 \% \mathrm{~N}_{2}$ gas in the flow-through system for 5 days. After the gas treatments, shoots were placed on the bench top in the controlled-temperature room at 20C to observe leaf abscission.

\section{Results}

Aluminum oxide effect. In the treatment of $1 \mu \mathrm{l} \cdot$ liter $^{-1}$ ethylene for $72 \mathrm{~h}$, shoots in the solution containing $\mathrm{Al}_{2} \mathrm{O}_{3}$ abscised a few more leaves than those without $\mathrm{Al}_{2} \mathrm{O}_{3}$ after 3 days of posttreatment observation(Fig. 1B). There was no clear difference in leaf abscission among the other ethylene treatments with or without $\mathrm{Al}_{2} \mathrm{O}_{3}$ (Fig. 1).

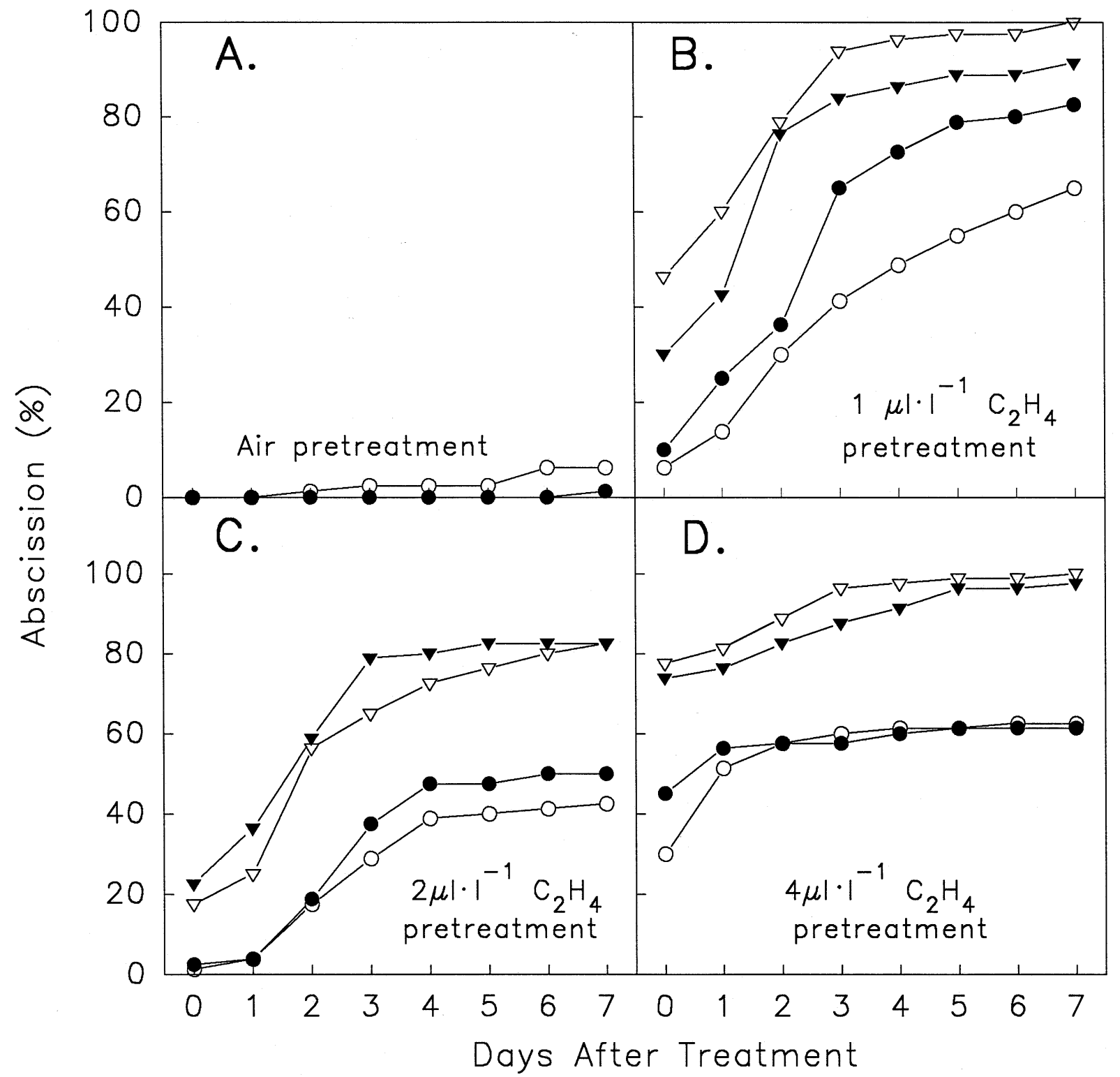

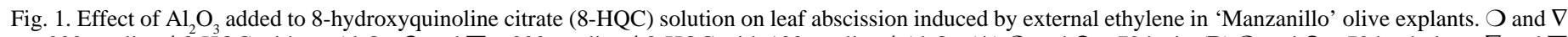

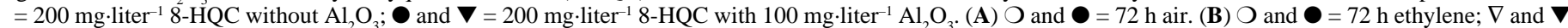
$=96 \mathrm{~h}$ ethylene. $(\mathbf{C}) \bigcirc$ and $\boldsymbol{O}=48 \mathrm{~h}$ ethylene; $\nabla$ and $\boldsymbol{\nabla}=72 \mathrm{~h}$ ethylene. (D) $\bigcirc$ and $\bigcirc=48 \mathrm{~h}$ ethylene; $\nabla$ and $\boldsymbol{\nabla}=72 \mathrm{~h}$ ethylene. 
Low concentration of ethylene treatment. At $791 \mathrm{nl} \cdot \mathrm{liter}^{-1}$ ethylene for $72 \mathrm{~h}$, ethylene evolution was low until $6 \mathrm{~h}$ after removal from ethylene treatment (Fig. 2A). By $24 \mathrm{~h}$ after removal from ethylene treatment, ethylene production increased up to 2.4 $\mathrm{nl} / \mathrm{leaf}$ per $\mathrm{h}$ and then returned to $<0.5 \mathrm{nl} / \mathrm{leaf}$ per $\mathrm{h}$. Leaves in this treatment started to abscise $72 \mathrm{~h}$ after removal from ethylene (Fig. 2D). Ethylene evolution from the shoots treated with 791 $\mu \mathrm{l} \cdot$ liter $^{-1}$ ethylene for $96 \mathrm{~h}$ was similar to that treated for $72 \mathrm{~h}$, except that it remained at 0.8 to $1.0 \mathrm{nl} / \mathrm{leaf}$ per $\mathrm{h}$ after the peak of ethylene evolution of $2.5 \mathrm{nl} / \mathrm{leaf}$ per $\mathrm{h}$ at $24 \mathrm{~h}$ after removal from ethylene (Fig. 2B). At the time of removal from $96 \mathrm{~h}$ of $791 \mu \mathrm{l} \cdot$ liter $^{-}$ ${ }^{1}$ ethylene, $20 \%$ of the leaves had abscised and abscission gradually increased subsequently (Fig. 2E). At $791 \mu \mathrm{l} \cdot$ liter $^{-1}$ ethylene for 120 $\mathrm{h}$, ethylene evolution $2 \mathrm{~h}$ after removal from treatment was already higher than that at 72 or $96 \mathrm{~h}$ (Fig. $2 \mathrm{~A}$ and B vs. C). However the maximum ethylene evolution was 2 nl/leaf per h (Fig. 2C). Leaf abscission at $791 \mu \mathrm{l} \cdot$ liter $^{-1}$ ethylene for $120 \mathrm{~h}$ was $48 \%$ at the time of removal from treatment and gradually increased during posttreatment observation (Fig. 2F). Treatment with ethylene at 193 $\mathrm{nl} \cdot$ liter $^{-1}$ for $120 \mathrm{~h}$ led to elevated ethylene evolution by $24 \mathrm{~h}$ after removal from treatment, and, after another $72 \mathrm{~h},<0 \%$ leaf abscission occurred (Fig. $2 \mathrm{C}$ and F). Ethylene at 193 nl.liter ${ }^{-1}$ for 72 and $96 \mathrm{~h}$ and at $47 \mathrm{nl} \cdot \mathrm{liter}^{-1}$ for 72 to $120 \mathrm{~h} \mathrm{did} \mathrm{not} \mathrm{affect} \mathrm{subsequent}$ ethylene evolution and/or leaf abscission when removed from treatment (Fig. 2 A-F).

Ethylene biosynthesis inhibitors. The control containing 8HQC alone resulted in no leaf abscission and ethylene evolution remained at $0.1 \mathrm{nl} / \mathrm{leaf}$ per $\mathrm{h}$ for 10 days (Fig. $3 \mathrm{~A}$ and D). At 40 mM NaH $\mathrm{PO}_{4}$, there was a slight increase of ethylene evolution at 8 and 9 days of treatment, while leaf abscission started to occur at 4 days of treatment and attained $50 \%$ abscission by 10 days (Fig. $3 \mathrm{~B}$ and $\mathrm{E}$ ). At $75 \mathrm{~mm} \mathrm{NaH} \mathrm{PO}_{4}$, leaf abscission started at 3 days of treatment and increased up to $80 \%$ by 10 days (Fig. $3 \mathrm{~F}$ ). Ethylene production at $75 \mathrm{~mm} \mathrm{NaH} \mathrm{PO}_{4}$ was $0.4 \mathrm{nl} / \mathrm{leaf}$ per $\mathrm{h}$ by 2 days of treatment and then increased to $1.6 \mathrm{nl} /$ leaf per h at 6 days (Fig. 3C). At 7 days, ethylene evolution decreased and then gradually increased by 10 days to the level attained previously at 6 days. These results formed the control $\mathrm{P}$-induced abscission comparison against which subsequent ethylene biosynthesis inhibitors could be compared.

AOA alone resulted in ethylene evolution and leaf abscission

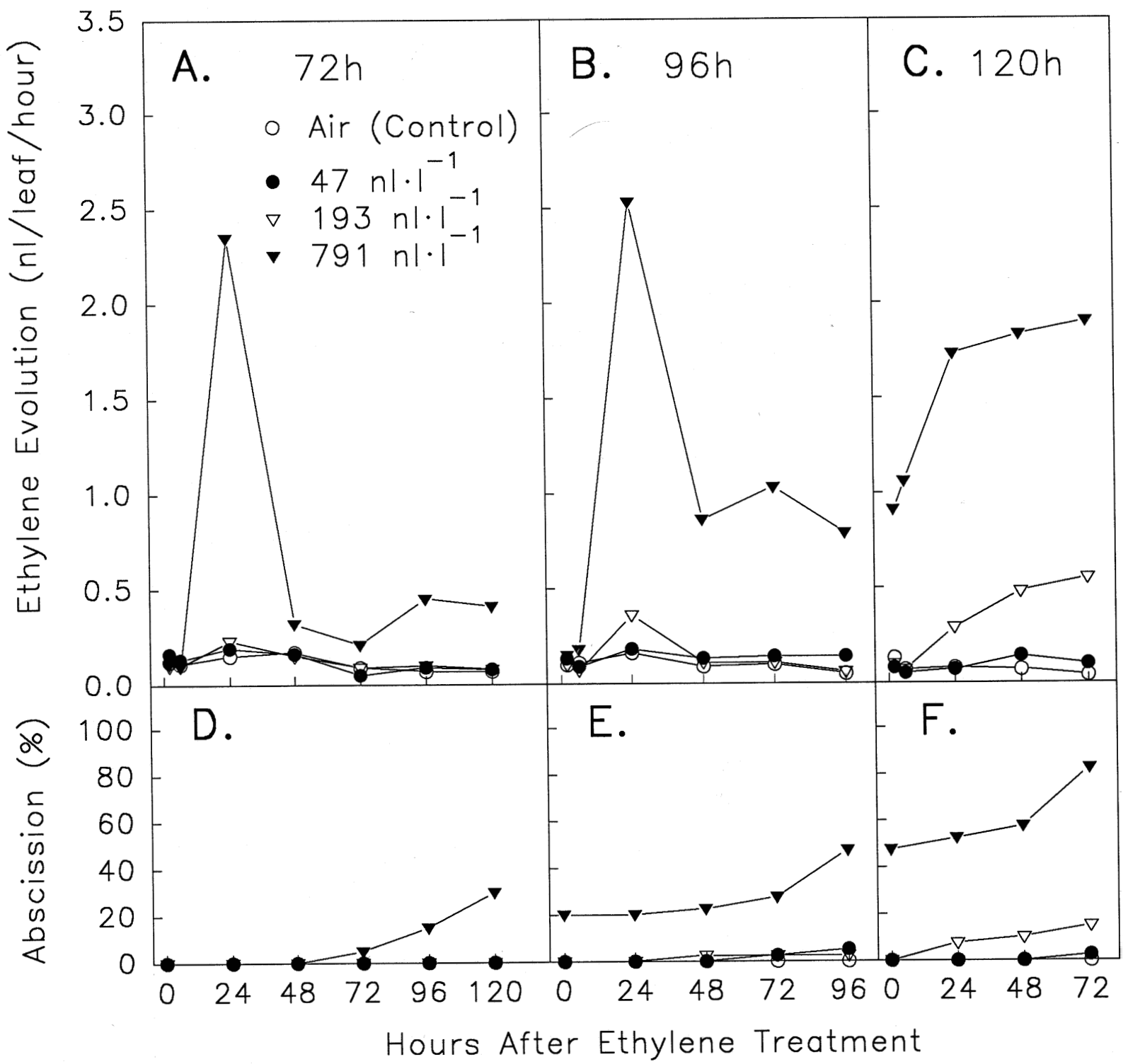

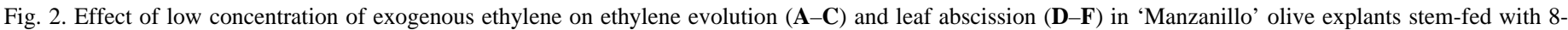
hydroxyquinoline citrate solution. The ethylene treatment duration is shown for each column as follows: (A and D) 72 h, (B and E) 96 h, and (C and F) 120 h. 
after 5 days of treatment (Fig. $4 \mathrm{~A}$ and D). At $40 \mathrm{~mm}$ and $75 \mathrm{~mm}$ $\mathrm{NaH}_{2} \mathrm{PO}_{4}$ with AOA, leaf abscission began by 3 days of treatment and achieved $100 \%$ leaf abscission by 5 or 9 days depending on AOA concentration (Fig. 4 B, C, E, and F). In all cases, ethylene evolution increased coincidentally with the increase of cumulative leaf abscission. In most cases, 5 mM AOA promoted leaf abscission and ethylene evolution slightly more than $2.5 \mathrm{~mm}$ AOA.

Cobalt chloride alone at all three concentrations induced ethylene evolution and leaf abscission (Fig. $5 \mathrm{~A}$ and D). At $5 \mathrm{~mm} \mathrm{CoCl}$, ethylene induction at $3 \mathrm{nl} / \mathrm{leaf}$ per $\mathrm{h}$ was greater than for any other treatment in these experiments (compare Figs. 3-6), yet it resulted in $<20 \%$ leaf abscission (Fig. $5 \mathrm{~A}$ and D). When $\mathrm{CoCl}_{2}$ was combined with 40 or $75 \mathrm{~mm} \mathrm{NaH}_{2} \mathrm{PO}_{4}$, ethylene evolution was $<1.5$ nl/leaf per $\mathrm{h}$ (Fig. $5 \mathrm{~B}$ and C). The latter treatments at 1.25 and 2.5 $\mathrm{mm} \mathrm{CoCl}$ led to $100 \%$ leaf abscission by 6 or 7 days, whereas 5 mM CoCl 2 combined with $\mathrm{NaH}_{2} \mathrm{PO}_{4}$ resulted in less leaf abscission than $\mathrm{NaH}_{2} \mathrm{PO}_{4}$ alone (Fig. 3 vs. 5).

Either alone or with $\mathrm{NaH}_{2} \mathrm{PO}_{4}, \mathrm{AVG}$ accelerated leaf abscission even though ethylene evolution remained $<0.5 \mathrm{nl} / \mathrm{leaf}$ per $\mathrm{h}$ in each treatment (Fig. $6 \mathrm{~A}-\mathrm{F}$ ).
Nitrogen gas effect. Leaf abscission was induced by 5 days of $\mathrm{NaH}_{2} \mathrm{PO}_{4}$ treatment when in ambient air, whereas no leaf abscission occurred when exposed to $100 \% \mathrm{~N}_{2}$ gas (Table 1). By 3 days of posttreatment, leaf abscission on explants stem-fed with 40 and $75 \mathrm{~mm} \mathrm{NaH}_{2} \mathrm{PO}_{4}$ and exposed to air increased to $55 \%$ and $95 \%$, respectively. Delayed leaf abscission was evident in $\mathrm{N}_{2}$ treatments combined with $\mathrm{NaH}_{2} \mathrm{PO}_{4}$ until exposed to ambient air. Leaf abscission in the $\mathrm{N}_{2}$-treated population began $24 \mathrm{~h}$ after removal from treatment, achieving $57.5 \%$ and $52.5 \%$, respectively, by 3 days of posttreatment observation (Table 1). Nitrogen gas alone did not induce leaf abscission by 3 days of posttreatment.

\section{Discussion}

Banno et al. (1993) showed that adding $\mathrm{Al}_{2} \mathrm{O}_{3}$ to a solution of ethephon or $\mathrm{NaH}_{2} \mathrm{PO}_{4}$ delayed leaf abscission compared with ethephon or $\mathrm{NaH}_{2} \mathrm{PO}_{4}$ alone. These authors maintained that this result was evidence that $\mathrm{Al}_{2} \mathrm{O}_{3}$ in the treatment solution directly affected leaf abscission by adsorbing P. It can also be argued that $\mathrm{Al}_{2} \mathrm{O}_{3}$ temporarily decreased the sensitivity of the abscission zone

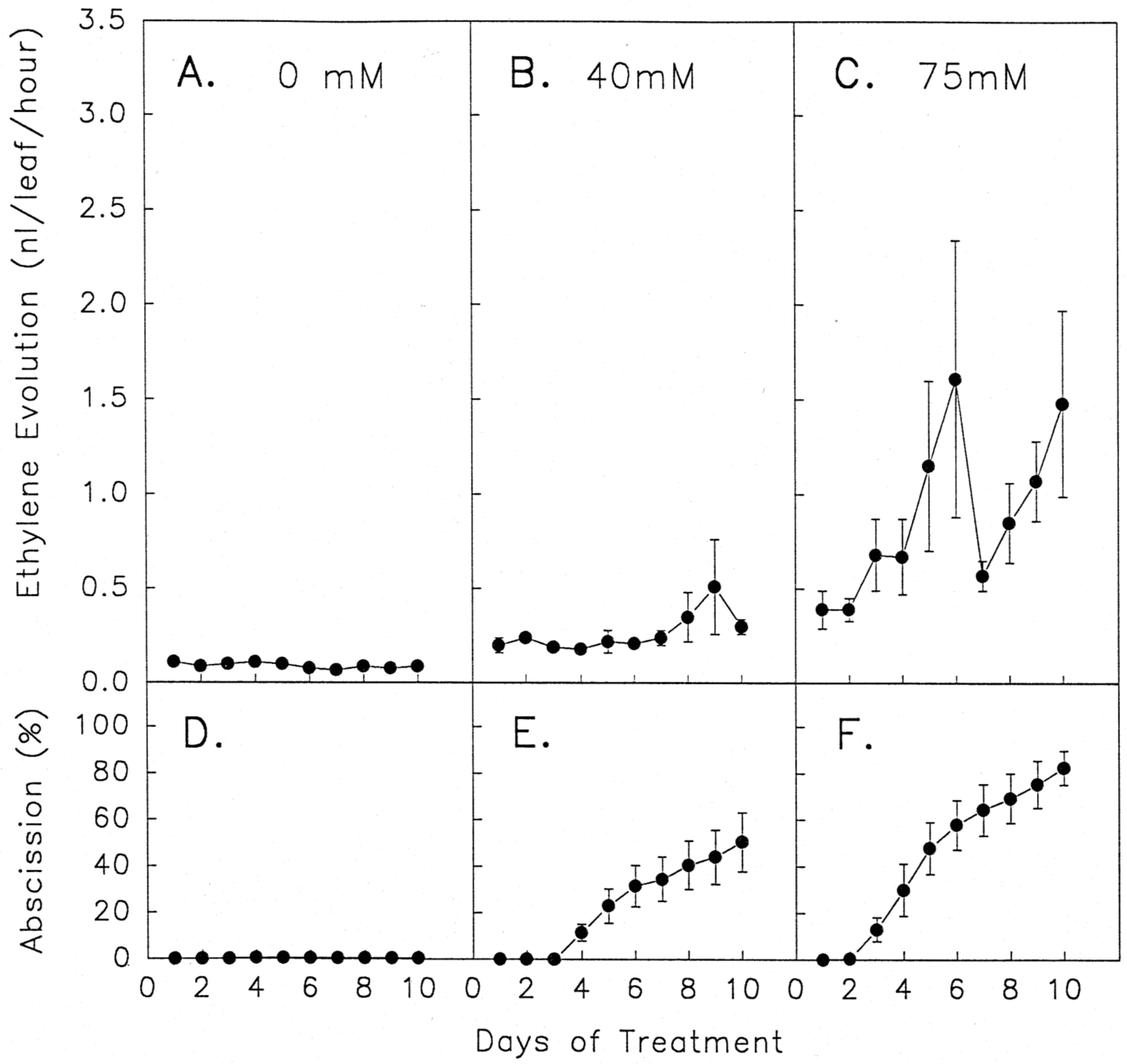

Fig. 3. Effect of 8-hydroxyquinoline citrate solution containing different concentrations of $\mathrm{NaH}_{2} \mathrm{PO}_{4}(0,40$, and 75 mM) on ethylene evolution (A-C) and leaf abscission (D-F) in 'Manzanillo' olive explants. Bars show SE. 
to ethylene, delaying abscission. We tested that interpretation by adding $\mathrm{Al}_{2} \mathrm{O}_{3}$ to 8 -HQC using several concentrations of external ethylene for different durations. Leaf abscission occurred at a similar rate with or without $\mathrm{Al}_{2} \mathrm{O}_{3}$, a result indicating that $\mathrm{Al}_{2} \mathrm{O}_{3}$ does not affect the sensitivity of the abscission zone to ethylene in olive explants.

The data reported here and elsewhere suggested that ethylene concentrations $<50 \mathrm{nl} \cdot$ liter $^{-1}$ have little or no effect on olive leaf abscission. The effect of low concentrations of external ethylene on olive leaf abscission was investigated by Burnik-Tiefengraber et al. (1994), but they did not determine endogenous ethylene evolution from explants after ethylene treatment. We measured ethylene production after exogenous ethylene treatment to determine whether subsequent leaf abscission was influenced by endogenous ethylene evolution. Leaf abscission occurred at the end of 96 or $120 \mathrm{~h}$ ethylene at $791 \mathrm{nl} \cdot$ liter $^{-1}$, whereas ethylene evolution after $96 \mathrm{~h}$ ethylene at $791 \mathrm{nl} \cdot$ liter $^{-1}$ was very low until $6 \mathrm{~h}$ after removal from treatment. Goren et al. (1988) applied a wide range of exogenous ethylene concentrations to detached olive leaves and found that $>960 \mathrm{nl} \cdot$ liter $^{-1}$ external ethylene induced autoenhancement of endogenous ethylene 96 or $120 \mathrm{~h}$ after exposure to ethylene. They also reported no relationship between the autoenhancement of ethylene and leaf abscission. Our data also showed a similar lag time of $120 \mathrm{~h}$ before autoenhancement of ethylene production, a time by which $50 \%$ abscission was already taking place. The shoots exposed to $791 \mathrm{nl} \cdot \operatorname{liter}^{-1}$ ethylene for 72 or $96 \mathrm{~h}$ had a peak of ethylene evolution at $24 \mathrm{~h}$ after ethylene treatment. Lavee and Martin (1981d) showed that short-term ethylene evolution induced by pulse-feeding ACC had a very limited effect on leaf abscission. Thus, these short-duration peaks of ethylene evolution do not seem to induce leaf abscission, even when magnitudes of order higher in concentration. Lavee and Martin (1981b) reported 50\% leaf abscission with $9.3 \mathrm{nl} \cdot \mathrm{g}^{-1}$ fresh weight per h ( 2 nl/leaf per h) ethylene evolution measured after $120 \mathrm{~h}$ of continuous stem-feeding with $50 \mathrm{mg} \cdot \mathrm{liter}^{-1}$ ethephon. In our studies, 1.7 to $1.9 \mathrm{nl} /$ leaf per h endogenous ethylene evolution 24 to $72 \mathrm{~h}$ after $791 \mathrm{nl} \cdot$ liter $^{-1}$ ethylene for $120 \mathrm{~h}$ may induce further leaf abscission. In both experiments, abscission may have resulted

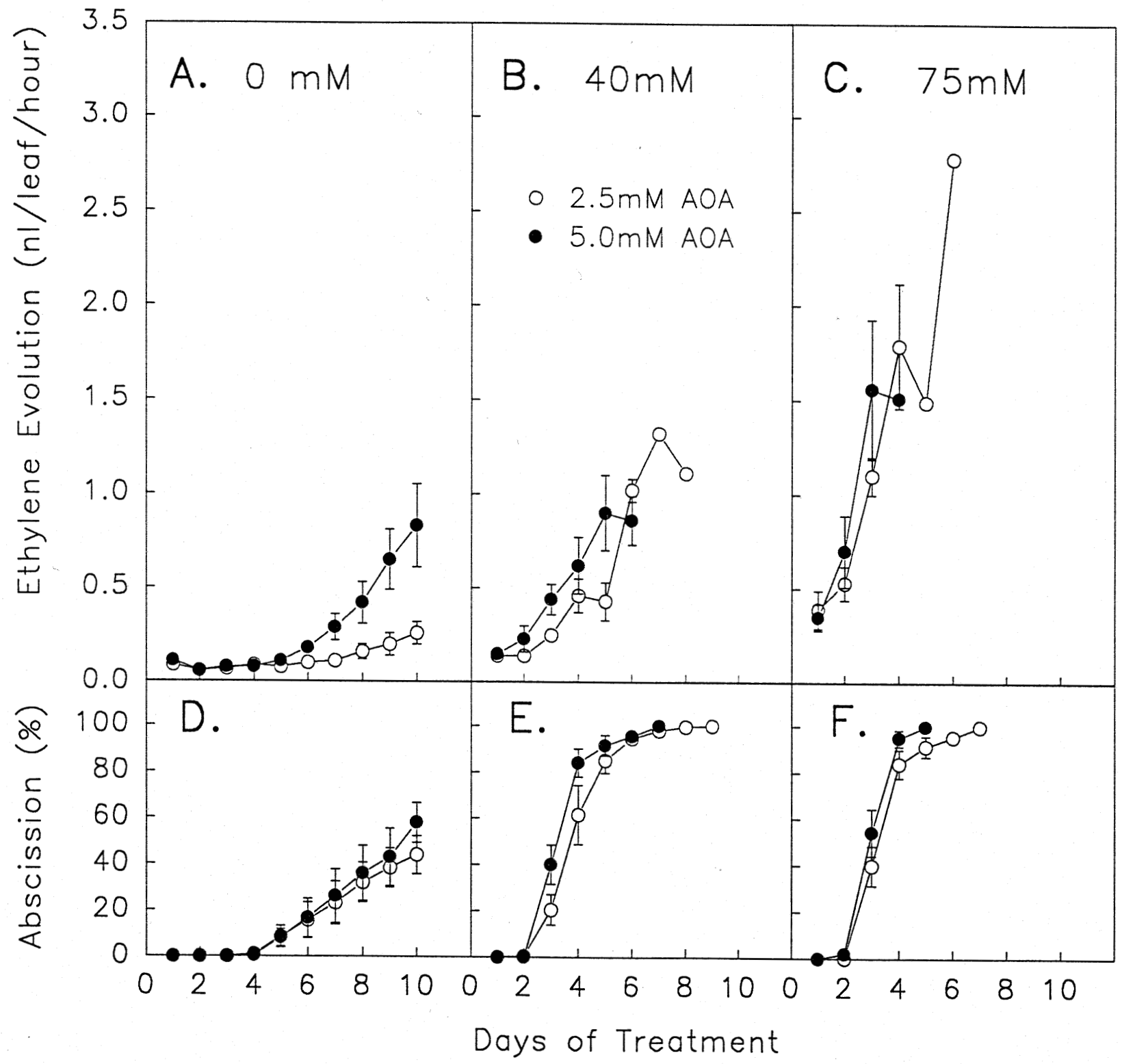

Fig. 4. Effect of AOA in 8-hydroxyquinoline citrate (8-HQC) solution with or without $\mathrm{NaH}_{2} \mathrm{PO}_{4}$ on ethylene evolution (A-C) and leaf abscission (D-F) in 'Manzanillo' olive explants. The concentration shown at the top of each column indicates the concentration of $\mathrm{NaH}_{2} \mathrm{PO}_{4}$ in 8 -HQC solution. Bars show SE. 
from continuous treatment with ethephon or ethylene without relation to evolved endogenous ethylene.

The leaf abscission response to $\mathrm{P}$ treatment reported by Banno et al. (1993) and Burnik-Tiefengraber et al. (1994), occurred at lower $\mathrm{P}$ concentrations than results reported here. They achieved $100 \%$ leaf abscission after 6 days of $25 \mathrm{~mm} \mathrm{NaH}_{2} \mathrm{PO}_{4}$ or 8 days of $75 \mathrm{~mm} \mathrm{NaH} \mathrm{PO}_{4}$, respectively. This may, in part, reflect the recovery of the trees used in these studies from the severe freeze damage of December 1990. During the 1991 growing season, leaf abscission was common even on trees without apparent freeze damage. We suggest that explants taken from those trees during 1991 would contain leaves that were more likely to abscise when treated with $\mathrm{NaH}_{2} \mathrm{PO}_{4}$. It is well known that exposure to ethylene gas or ethephon is required to precede leaf abscission (Lang and Martin, 1987, 1989; Lavee and Martin, 1981a, 1981b, 1981d). Banno et al. (1993) doubted the dependence of P-induced abscission on ethylene production, because in their experiment ethylene evolution following $\mathrm{P}$ stem-feeding paralleled rather than preceded leaf abscission. In our experiments, ethylene evolution from the explants stem-fed with $75 \mathrm{~mm} \mathrm{NaH} \mathrm{PO}_{4}$ increased coinciden- tally with the increase of cumulative leaf abscission, a result that agrees with the results of Banno et al. (1993) and BurnikTiefengraber et al. (1994). In our studies, olive explants stem-fed with $40 \mathrm{~mm} \mathrm{NaH} \mathrm{PO}_{4}$ did not increase ethylene evolution until after 8 days of treatment, when only a slight increase of ethylene at $<0.5 \mathrm{nl} /$ leaf per h occurred and by which time $40 \%$ leaf abscission had occurred. This suggests the independence of P-induced leaf abscission from that of $\mathrm{P}$ effects on ethylene production.

Using ethylene biosynthesis inhibitors led to unexpected results in the olive explant system. Although Burnik-Tiefengraber et al. (1994) used AOA to determine whether P caused leaf abscission by elevating ethylene evolution, AOA did not affect P-induced leaf abscission or ethylene evolution. Since the response and sensitivity to a certain inhibitor may change depending on the tissue treated and application method (Yang, 1980), we tried AOA, AVG, and $\mathrm{CoCl}_{2}$ applied via the stem in solution. Each inhibitor had different effects on ethylene evolution from explants stem-fed with $\mathrm{P}$ or inhibitor alone. All of these inhibitors except $5 \mathrm{mM} \mathrm{CoCl}_{2}$, however, promoted leaf abscission with or without $\mathrm{P}$. In contrast to the report by Burnik-Tiefengraber et al. (1994), AOA accelerated leaf

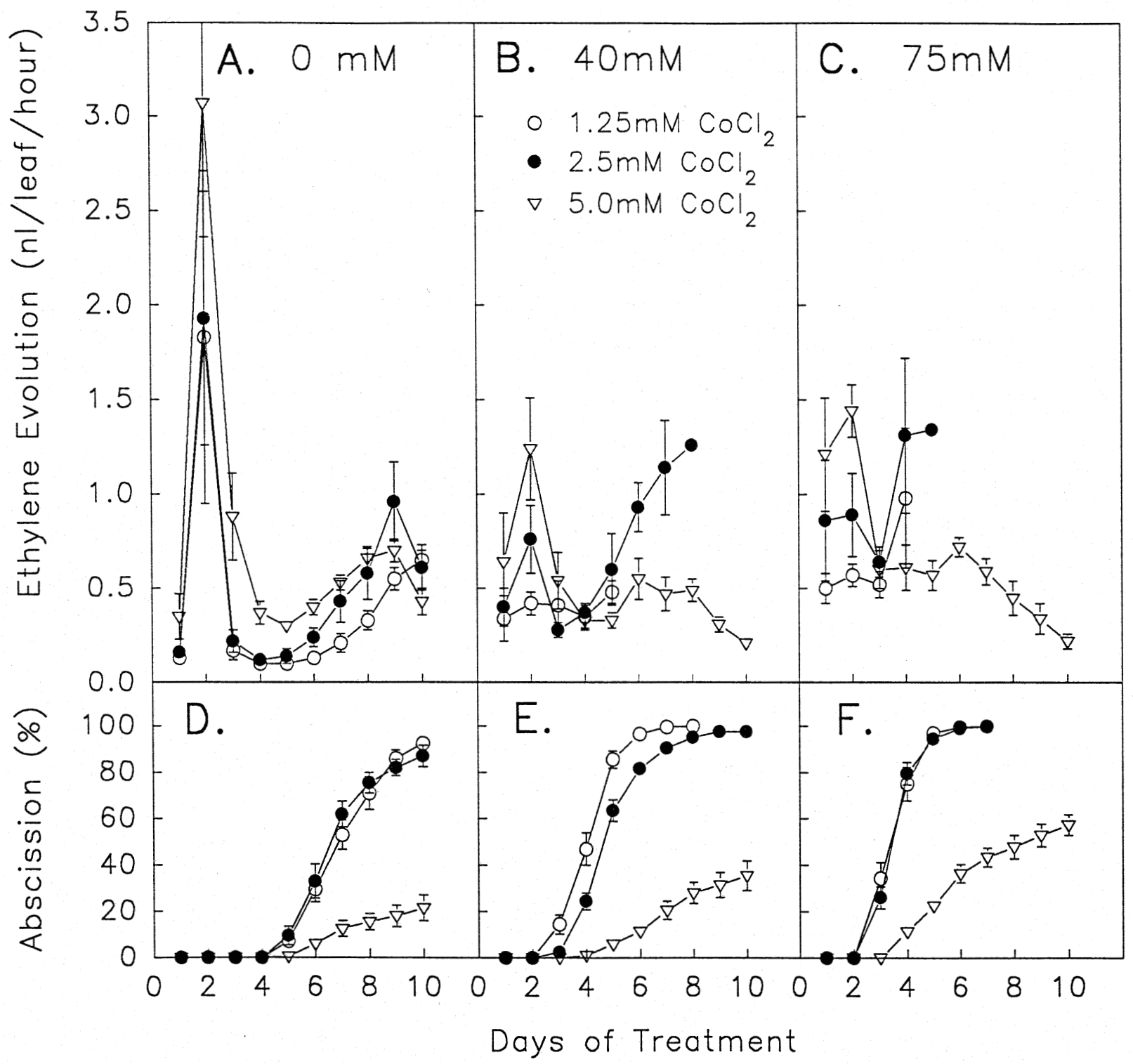

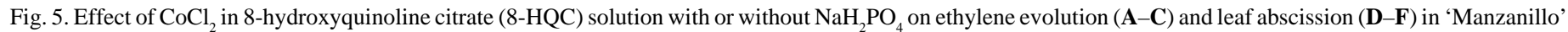

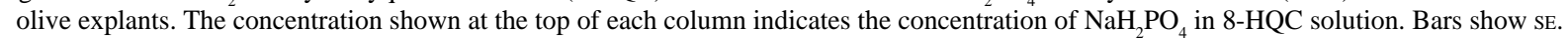


abscission in the solutions with $\mathrm{P}$ and AOA alone. Since in their experiment with $\mathrm{P}$ leaf abscission occurred more rapidly than in our experiments, this positive effect of AOA could have been masked in their experiment. Cobalt chloride is known as an ethylene inhibitor that blocks the conversion of ACC to ethylene (Lau and Yang, 1976; Yang, 1980). Adding $\mathrm{CoCl}_{2}$ at three concentrations with $\mathrm{P}$ or $\mathrm{CoCl}_{2}$ alone increased ethylene evolution at 2 days of treatment, and the amount of ethylene at that time was positively related to the concentration of $\mathrm{CoCl}_{2}$. Development of necrosis on the leaves and promotion of ethylene evolution indicated that $\mathrm{CoCl}_{2}$ was a phytotoxic compound rather than an ethylene biosynthesis inhibitor in olives. Inhibition of leaf abscission with severe necrosis and desiccation at $5 \mathrm{~mm} \mathrm{CoCl}_{2}$ also supports this contention and coincides with the same phenomenon on olive inflorescence treated with high ethephon concentrations (Weis et al., 1988).

It was reported that AVG inhibited ethylene evolution induced by wounding in detached olive leaves (Lavee and Martin, 1981c). In our results, even though AVG almost completely inhibited ethylene evolution, AVG promoted leaf abscission alone or with $\mathrm{P}$.
This observation clearly separates the leaf abscission action of $\mathrm{P}$ from the requirement for ethylene evolution. Abeles and Wydoski (1987) indicated a promotive effect of AVG on lettuce root growth in air and in the presence of ethylene. They also showed that AVG, AOA, and L-canaline inhibited root elongation at high concentrations, although those compounds strongly inhibited ethylene production. These observations and the data reported here suggest that ethylene biosynthesis inhibitors have their own action on growth and abscission in addition to inhibiting ethylene evolution (Abeles and Wydoski, 1987).

Leaf abscission occurred in the shoots stem-fed $\mathrm{P}$ in ambient air but did not occur in $100 \% \mathrm{~N}_{2}$ gas at 5 days of treatment. The quick response of leaf abscission when transferred from $\mathrm{N}_{2}$ to aerobic conditions, however, suggests that the amount of $\mathrm{P}$ retained in the explant was enough to induce leaf abscission and that $\mathrm{O}_{2}$ was required for $\mathrm{P}$-induced abscission.

In conclusion, four hypotheses were tested and we interpret our results as follows: 1) $\mathrm{Al}_{2} \mathrm{O}_{3}$ does not decrease the sensitivity of the abscission zone to ethylene treatment, 2) ethylene at 47 or 193 nl.liter ${ }^{-1}$ for 4 days does not induce leaf abscission or endogenous

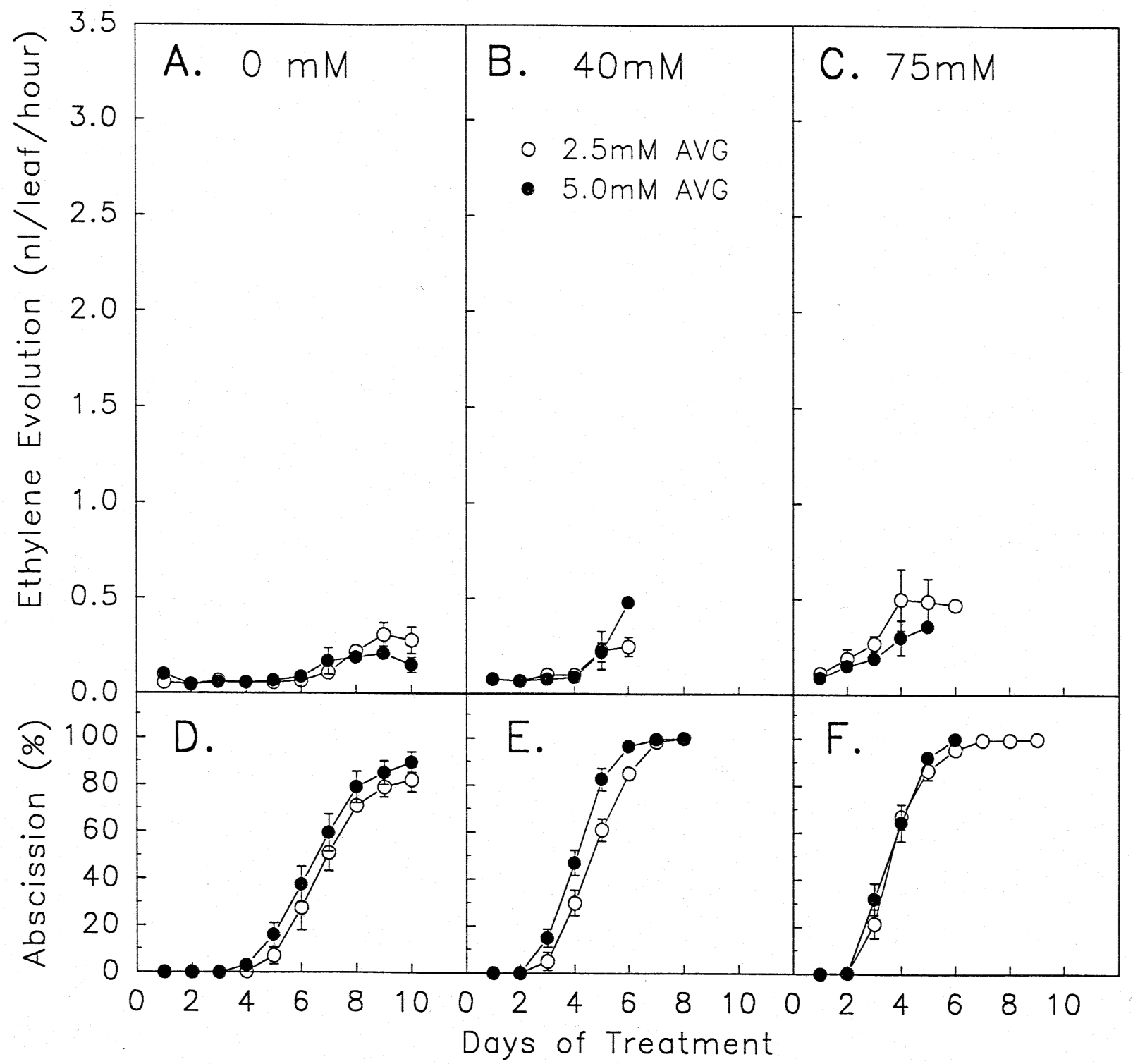

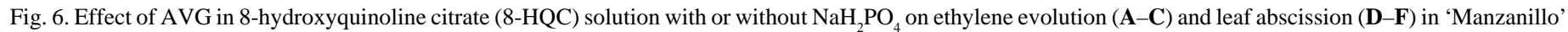

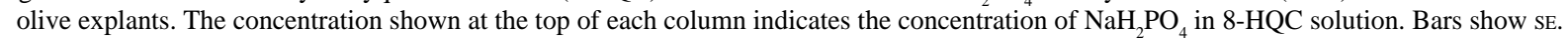


Table 1. Effect of $\mathrm{N}_{2}$ gas treatment on P-induced leaf abscission in 'Manzanillo' olive explants.

\begin{tabular}{lcccc}
\hline & & \multicolumn{3}{c}{ Leaf abscission $(\%)^{\mathrm{z}}$} \\
\cline { 3 - 5 } $\mathrm{NaH}_{2} \mathrm{PO}_{4}$ & & $\begin{array}{c}\text { 5 Days of } \\
\text { concn }(\mathrm{mM})\end{array}$ & $\begin{array}{c}\text { 1 Day of } \\
\text { posttreatment }\end{array}$ & $\begin{array}{c}\text { 3 Days of } \\
\text { posttreatment }\end{array}$ \\
\hline 0 & Air & 0 & 0 & 0 \\
& $\mathrm{~N}_{2}$ & 0 & 0 & 0 \\
40 & $\mathrm{Air}$ & 12.5 & 25.0 & 55.0 \\
75 & $\mathrm{~N}_{2}$ & 0 & 35.0 & 57.5 \\
& $\mathrm{Air}$ & 45.0 & 62.5 & 95.0 \\
& $\mathrm{~N}_{2}$ & 0 & 52.5 & 52.5 \\
\hline
\end{tabular}

${ }^{\mathrm{z}}$ Explants were treated for 5 days in jars, then removed to ambient conditions in the laboratory at $20 \mathrm{C}$ for postharvest treatment observation.

ethylene evolution and leaf abscission that occurred at 791 nl-liter ${ }^{-1}$ ethylene does not seem to be induced by endogenous ethylene, 3) P-induced leaf abscission occurs independent of endogenous ethylene evolution, and 4) $\mathrm{O}_{2}$ is required for Pinduced leaf abscission.

\section{Literature Cited}

Abeles, F.B. and S.G. Wydoski. 1987. Inhibitors of ethylene synthesis and action: A comparison of their activities in a lettuce root growth model system. J. Amer. Soc. Hort. Sci. 112:122-125.

Banno, K., G.C. Martin, and R.F. Carlson. 1993. The role of phosphorus as an abscission-inducing agent for olive leaves and fruit. J. Amer. Soc. Hort. Sci. 118:599-604.

Ben-Tal, Y. and S. Lavee. 1976. Increasing the effectiveness of ethephon for olive harvesting. HortScience 11:489-490.

Burnik-Tiefengraber, T., K.G. Weis, G.C. Martin, H. Yamada, and B.D. Webster. 1994. Phosphate effect on olive leaf abscission. J. Amer. Soc. Hort. Sci. 119:765-769.

Fuchs, Y., A.K. Mattoo, E. Chalutz, and I. Rot. 1981. Biosynthesis of ethylene in higher plants: The metabolic site of inhibition by phosphate. Plant Cell Environ. 4:291-295.
Goren, R., C. Nishijima, and G.C. Martin. 1988. Effects of external ethylene on the production of endogenous ethylene in olive leaf tissue. J. Amer. Soc. Hort. Sci. 113:778-783.

Hartmann, H.T., A. Tombesi, and J. Whisler. 1970. Promotion of ethylene evolution and fruit abscission in the olive by 2-chloroethane phosphonic acid and cycloheximide. J. Amer. Soc. Hort. Sci. 95:635-640.

Lang, G.A. and G.C. Martin. 1987. Ethylene-induced olive organ abscission: Ethylene pulse treatments improve fruit-to-leaf abscission ratios. Acta Hort. 201:43-52.

Lang, G.A. and G.C. Martin. 1989. Olive organ abscission: Fruit and leaf response to applied ethylene. J. Amer. Soc. Hort. Sci. 114:134-138.

Lau, Oi-Lim and S.F. Yang. 1976. Inhibition of ethylene production by cobaltous ion. Plant Physiol. 58:114-117.

Lavee, S. and G.C. Martin. 1981a. In vitro studies on ethephon-induced abscission in olive. I. The effect of application period and concentration on uptake, ethylene evolution, and leaf abscission. J. Amer. Soc. Hort. Sci. 106:14-18.

Lavee, S. and G.C. Martin. 1981b. In vitro studies of ethephon-induced abscission in olive. II. The relation between ethylene evolution and abscission of various organs. J. Amer. Soc. Hort. Sci. 106:19-26.

Lavee, S. and G.C. Martin. 1981c. Ethylene evolution from various developing organs of olive (Olea europaea) after excision. Physiol. Plant. 51:33-38.

Lavee, S. and G.C. Martin. 1981d. Ethylene evolution following treatment with 1-aminocyclopropane-1-carboxylic acid and ethephon in an in vitro olive shoot system in relation to leaf abscission. Plant Physiol. 67:1204-1207.

Martin, G.C. 1986. Olive harvest in California, United States of America. Olivae 3:11-20.

Martin, G.C., S. Lavee, and G.S. Sibbett. 1981. Chemical loosening agents to assist mechanical harvest of olive. J. Amer. Soc. Hort. Sci. 106:325-330.

Sobolewska, J. and H. Plich. 1986. The effect of inorganic phosphate on the ethylene production in tomato and apple fruits. Biol. Plant. 28:9599.

Weis, K.G., R. Goren, G.C. Martin, and B.D. Webster. 1988. Leaf and inflorescence abscission in olive. I. Regulation by ethylene and ethephon. Bot. Gaz. 149:391-397.

Yang, S.F. 1980. Regulation of ethylene biosynthesis. HortScience 15:238243. 